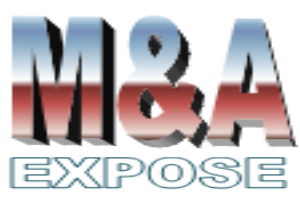

http://jurnal.usahid.ac.id/index .php/accounting
Fakultas Ekonomi dan Bisnis Universitas Serang Raya adenahdiatul88@amail.com

\section{Pengaruh Degree of Operating Leverage dan Degree of Financial Leverage terhadap Return On Equity}

\section{Ade Nahdiatul Hasanah}

\section{Abstrak}

Penelitian ini bertujuan untuk mengetahui pengaruh leverage dalam pendanaan terhadap tingkat keuntungan yang diperoleh pada perusahaan manufaktur di sektor makanan dan minuman yang terdaftar di Bursa Efek Indonesia periode 2010-2014. Penelitian menggunakan teknik analisis regresi berganda. Sampel penelitian sebanyak lima perusahaan dengan menggunakan metode purposive sampling. Data yang digunakan dalam penelitian adalah data sekunder berupa laporan tahunan dan keuangan. Berdasarkan hasil penelitian dapat disimpulkan bahwa operation leverage dan financial laverage berpengaruh negatif namun tidak siginifikan terhadap return on equity. Adapun di antara proxy leverage pendanaan yang digunakan, yang paling dominan pengaruhnya adalah financial leverage.

Kata Kunci : Degree of Operation Leverage, Degree of Financial Leverage, Return on Equity.

\section{Abstract}

This study aims to determine the effect of leverage in funding on the level of profits obtained by companies in manufacturing companies in the food and beverage sector listed on the Indonesian Stock Exchange for the 2010-2014 period. The study used multiple regression analysis techniques. The research samples were five companies using purposive sampling method. The data used in the study are secondary data in the form of annual reports and financial. Based on the results of the study it can be concluded that operation loan and financial leverage have a negative effect but are not significant, and among proxy funding funding used financial leverage is the most dominantly influential.

Keywords : Degree of Operation Leverage, Degree of Financial Leverage, Return on Equity. 


\section{PENDAHULUAN}

Investasi yang dilakukan oleh para investor hendaknya memiliki keberlangsungan yang cukup lama, maka pemilihan investasi berdasarkan kelompok industrial sangatlah mencerminkan atas kebutuhan investasi tersebut. Pendanaan dalam kelompok industri barang konsumsi banyak menarik peminat (investor) karena dalam industri tersebut merupakan pemenuhan kebutuhan pokok manusia yang secara terus menerus dipakai.

Tingkat konsumsi masyarakat Indonesia sangat besar, Indonesia bukan hanya menjadi target pasar produk-produk luar negeri yang potensial, tetapi juga sebagai target investasi para investor. Berdasarkan kabar terakhir, sebuah private equity asal Amerika (KKR) baru saja mengakuisisi sepuluh persen kepemilikan di Tiga Pilar Sejahtera, salah satu perusahaan yang bergerak di sektor konsumsi (consumer goods). Pilihan investasi di sektor konsumsi bisa menjadi alternatif isi portofolio ketika investasi di perusahaan sektor lain masih menunjukan pelemahan kinerja. Misalnya, ketika sektor properti mengalami penurunan kinerja cukup signifikan sejak Bank Indonesia Rate dinaikkan dan akibat aturan Loan To Value yang baru. Juga di saat harga komoditas tambang dan perkebunan belum menunjukan kenaikan harga, sehingga emiten-emiten perkebunan dan pertambangan masih akan menurun kinerjanya. Meredupnya kinerja perusahaan di sektor lain mendorong investor mulai mencari alternatif investasi pada sektor yang masih bisa tumbuh. Salah satunya adalah sektor konsumsi.

Rata-rata pertumbuhan penjualan emiten-emiten ini masih cukup tinggi pada tahun 2012-2014. Penjualan di atas 30 persen namun besarnya beban operasional perusahaan menyebabkan banyak perusahaan sub sektor makanan dan minuman mengalami pencatatan laba bersih yang turun signifikan. Penjualan selama semester pertama tahun 2014 masih tumbuh 13 persen. Namun, beban operasional yang meningkat signifikan menjadikan laba bersihnya tergerus minus 44 persen. Meskipun beberapa perusahaan mencatatkan pertumbuhan laba negatif, namun masih ada perusahaan mencatatkan pertumbuhan laba bersih positif. Pertumbuhan laba bersih negatif di saat pertumbuhan pendapatan masih positif, mengindikasikan bahwa mayoritas perusahaan subsector makanan dan minuman mengalami masalah kenaikan biaya operasional. Benar saja. Perusahaan yang masih mencatat pertumbuhan laba bersih berkebalikan dengan pendapatan, seperti mengalami masalah pada efisiensi operasional perusahaan. Beberapa juga mengalami penurunan Net Profit Margin, namun perusahaan-perusahaan tersebut masih bisa mencatatkan kinerja positif. Perlu adanya kebijakan dalam menyingkapi kondisi tersebut berupa upaya-upaya yang dibuat oleh principal perusahaan.

Peran kebijakan perusahaan merupakan ketentuan-ketentuan yang ditetapkan oleh direksi kepada manajemen dalam pelaksanaan kegiatan usaha yang salah satunya merupakan kebijakan pendaaan dengan tujuan utama mengoptimalkan nilai perusahaan melalui penentuan struktur modal. Nilai perusahaan dianggap sebagai gambaran kinerja atas aktivitas-aktivitas bisnis berupa aktivitas pendanaan, aktivitas investasi dan aktivitas operasional.

Aktivitas pendanaan merupakan kemampuan manajemen dalam menentukan target struktur modal, dan mengaktifkan fungsi maupun peran aktiva sebagai kepemilikan utama perusahaan dalam definisi aktivitas investasi, sedangkan aktivitas operasional merupakan kemampuan manajemen dalam kegiatan operasi perusahaan. Kondisi keuangan dan hasil operasi perusahaan yang tercermin pada laporan keuangan disusun dengan maksud untuk 
memberikan informasi tentang hasil usaha, posisi keuangan dan berbagai faktor yang menyebabkan terjadinya perubahan posisi keuangan tersebut kepada semua pihak yang berkepentingan dengan eksistensi perusahaan. Informasi tentang kondisi keuangan dan hasil operasi perusahaan berguna untuk berbagai pihak, baik pihak dalam maupun pihak luar perusahaan.

Dalam teori manajemen keuangan, akan selalu ada trade-off antara resiko dan return. Jika resiko suatu investasi tinggi, maka return yang akan dihasilkan akan berbanding lurus, begitu juga sebaliknya. Maka, para manajer harus mengetahui resiko untuk dipertimbangkan dalam menilai dan memutuskan suatu keputusan investasi. Pemahaman akan penilaian trade-off antara resiko dan return ini akan membentuk landasan komposisi struktur modal dalam usaha memaksimalkan kesejahteraan para pemegang saham.

Berdasarkan latar belakang di atas maka penelitian ini akan menganalisis pengaruh arsial dan simultan operating leverage dan financial leverage terhadap return on equity perusahaan manufaktur sub sektor makanan dan minuman.

\section{TINJAUAN PUSTAKA}

Menurut Hanafi (2010), leverage adalah penggunaan aset dana sumber dana oleh perusahaan yang memiliki biaya tetap (beban tetap) dengan maksud agar meningkatkan keuntungan potensial pemegang saham. Jika semua biaya bersifat variabel, maka akan memberikan kepasatian bagi perusahaan dalam menghasilkan laba. Akan tetapi kerena biaya perusahaan bersifat tetap, maka untuk menghasilkan laba diperlukan tingkat penjualan minimum tertentu. Biaya tetap tidak tergantung dari tingkat penjualan opersional perusahaan, maka biaya ini menjadi resiko yang harus dikendalikan dan ditanggung oleh perusahaan. Konsep leverage sangat penting untuk menunjukkan analisis keuangan dalam melihat trade-off antara resiko dan tingkat keuntungan dari berbagai sudut keputusan yang terbaik. Ini merupakan tugas manajer keuangan agar dapat membuat perencanaan, analisis dan pengendalian kegiatan.

Terdapat beberapa jenis leverage yang dikembangkan dalam manajemen keuangan, di antaranya operating leverage dan financial leverage. Menurut Hanafi (2010) operating leverage adalah penggunaan aktiva yang menyebabkan perushaan harus menanggung biaya tetap berupa penyusutan. Operating leverage dikategorikan menguntungkan apabila perusahaan mampu menanggung biaya tetap atas penggunaan aktiva atau penjualan setelah dikurangi biaya variabel akan lebih besar dari biaya tetap. Sebaliknya operating leverage dikategorikan merugikan apabila perusahaan tidak mampu menutup biaya tetap atau penjualan dan pendapatan lebih kecil dari biaya tetap. Financial leverage menurut Hanafi (2010) adalah sejauh mana perusahaan menggunakan pendaan melalui hutang untuk meningkatkan kegiatan produksinya dan seberapa besar kemampuan laba untuk menutup biaya bunga.

Menurut Hanafi (2010) operating leverage adalah penggunaan aktiva yang menyebabkan perusahaan harus menanggung biaya atetap berupa penyusutan. Operating leverage dapat mengukur perubahan pendapatan atau penjualan terhadap keuntungan operasi perusahaan. Dilihat dari kegunaan operating leverage tesebut, dapat disimpulkan bahwa perusahaan dapat mengetahui perubahan laba operasi sebagai akibat perubahan penjualan, sehingga perusahaan dapat mengetahui keuntungan operasi perusahaan. 
Degree of Operating Leverage (DOL) dapat dihitung dengan menggunakan formula sebagai berikut (Hanafi, 2010) :

$$
\mathrm{DOL}=\frac{\text { Prosentase Perubahan EBIT }}{\text { Prosentase Perubahan Penjualan }}
$$

Financial leverage dapat diukur dengan menggunakan Degree of Financial Leverage (DFL). Degree of Financial Leverage (DFL) merupakan ukuran kuantitatif sensitivitas Earnings Per Shares perusahaan terhadap perubahan laba operasional (Husnan, 2006). Degree of Financial Leverage (DFL) dapat dihitung dengan menggunakan formula sebagai berikut (Husnan, 2006) :

$$
\mathrm{DFL}=\frac{\text { Prosentase Perubahan EPS }}{\text { Prosentase Perubahan EBIT }}
$$

Penelitian ini menggunakan Return on Equity (ROE) sebagai alat ukur profitabilitas. Alasan menggunakan ROE sebagai alat ukur profitabilitas karena ROE merupakan ukuran rasio profitabilitas dari sudut pandang pemegang saham. Pemegang saham tertarik pada ROE karena pemegang saham dapat melihat seberapa besar kemampuan perusahaan untuk memperoleh keuntungan terhadap modal yang telah iatanamkan.

Kasmir (2008) menyatakan bahwa semakin tinggi rasio ROE maka, semakin baik kondisi perusahaan karena return atau penghasilan yang diterima tinggi sehingga posisi pemilik perusahaan semakin kuat. Jika rasio ini rendah biasanya disebabkan karena kurang efektif dalam menggunakan modal. Return on Equity (ROE) dapat dihitung dengan menggunakan rumus berikut (Kasmir, 2008) :

$$
\text { ROE }=\frac{\text { Laba Bersih Setelah Pajak }}{\text { Total Ekuitas }}
$$

Agency Theory. Konsep teori keagenan adalah hubungan atau kontrak antara principal (pemilik) dan agen (manajemen). Principal adalah pemegang saham atau traditional users lain. Agen manajemen akan berupaya mengoperasikan perusahaan sesuai dengan keinginan publik. Agen diwajibkan memberikan laporan periodik pada principal tentang usaha yang dijalankan. Jadi, stakeholder atau investor tidak mempunyai kendali langsung atas keputusan yang dibuat oleh manajer, investor tahu bahwa manajer memiliki informasi, tetapi mereka tidak dapat mengetahui apakah itu (Husnan, 2006).

Masalah agency akan muncul ketika investor membutuhkan informasi yang cukup untuk mengijinkan trend perkiraan perusahaan dimasa yang akan datang, tetapi manajemen perusahaan tidak mengungkap informasi tersebut dalam laporan tahunan. Situasi ini, dalam literature hubungan agency, dikenal sebagai informasi asimetris. Informasi asimetris mengacu pada situasi dimana satu group individual (para manager) dinformasikan lebih baik (paling tidak pada awalnya) dibandingkan grup lainnya diluar investor.

Pecking Order Theory. Teori ini berimplikasi bahwa manajer akan berfikir dalam kerangka trade-off antara penghematan pajak dan biaya kebangkrutan dalam penentuan struktur modal. Dalam kenyataan empiris nampaknya jarang manajer keuangan yang berfikir demikian. Teori pecking order ini bisa menjelaskan mengapa perusahaan yang mempunyai tingkat keuntungan yang lebih tinggi justru mempunyai tingkat hutang yang lebih kecil.

Teori Berdasarkan Perilaku Manajemen. Teori ini menyatakan bahwa dalam pihak pihak yang berkaitan dengan perusahaan tidak mempunyai informasi yang sama mengenai 
prospek dan resiko perusahaan. Pihak tertentu mempunyai informasi yang lebih daripada pihak lainnya.

Berdasarkan tinjauan pustaka tersebut, maka model penelitian ini dapat diilustrasikan dalam kerangka penelitian sebagai berikut :

Gambar 1. Kerangka Penelitian

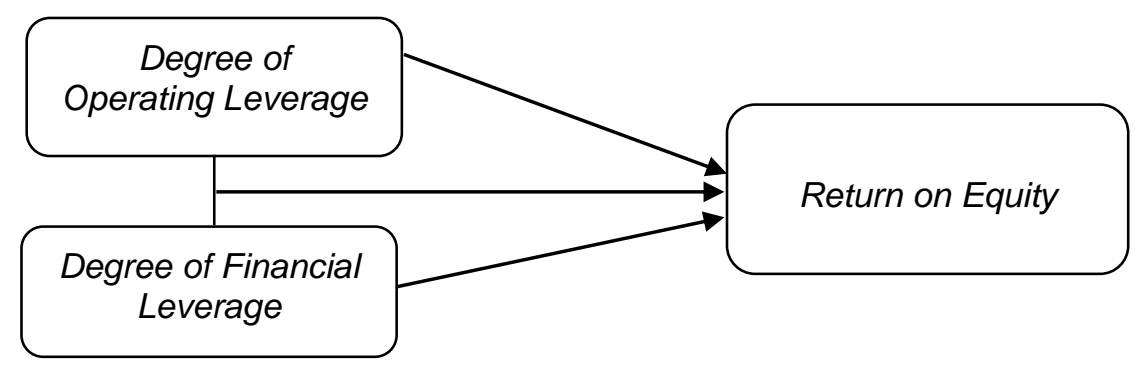

\section{METODE PENELITIAN}

Metode penelitian berjenis penelitian asosiatif, yaitu metode penelitian untuk menganalisis sebab akibat yang terdapat pada tingkat pengaruh variabel-variabel independen dengan variabel dependen. Variabel Independen berupa Degree of Operating Leverage dan Degree of Financial Leverage, sedangkan variabel dependen adalah Return on Equity.

Penelitian ini menggunakan data sekunder berupa iktisar laporan keuangan dan laporan keuangan perusahaan makanan dan minuman yang terdaftar di Bursa Efek Indonesia (BEI) periode 2012-2016. Terdapat lima belas perusahaan makanan dan minuman yang terdaftar di BEI dan lima di antaranya merupakan sampel yang terpilih dengan kriteria tertentu.

Uji Asumsi Klasik. Pengujian terhadap asumsi klasik bertujuan untuk mengetahui apakah suatu model regresi tersebut baik atau tidak jika digunakan untuk melakukan penaksiran. Suatu model disebut baik apabila bersifat BLUE (Best Linear unbiased Estimator), yaitu memenuhi asumsi klasik atau terhindar dari masalah-masalah multikolinieritas, heteroskedastisitas, autokorelasi mau pun uji Linearitas (Thobarry, 2009). Uji asumsi klasik melalui beberapa pengujian di antaranya:

1. Uji normalitas data bertujuan untuk menguji apakah dalam model variabel dependen dan variabel independen keduanya mempunyai distribusi normal atau tidak. Hal ini bertujuan untuk mengetahui jenis statistik yang cocok yang akan digunakan dalam menganalisis data. Model regresi yang baik adalah distribusi data normal atau mendekati normal. Pengujian normalitas ini dapat dilakukan melalui analisis grafik dan analisis statistik.

2. Uji multikolinieritas digunakan untuk menguji apakah dalam sebuah model regresi ditemukan adanya korelasi antarvariabel independen. Jika terjadi korelasi maka dikatakan terdapat masalah multikolinieritas, model regresi yang baik seharusnya tidak terjadi korelasi antarvariabel independen. Pengujian terhadap ada tidaknya multikolinieritas dilakukan dengan VIP (Variance Inflation Factor).

3. Uji autokorelasi bertujuan untuk menguji apakah dalam model regresi linear ada korelasi antara kesalahan pengganggu pada periode $t$ dengan kesalahan pengganggu pada 
periode t-1 (sebelumnya), jika terjadi korelasi, maka dinamakan ada problem autokorelasi. Autokorelasi muncul karena observasi yang berurutan sepanjang waktu berkaitan satu sama lainnya (Ghozali, 2006). Untuk menguji keberadaan autokorelasi dalam penelitian ini digunakan uji statistik Durbin-Watson.

4. Uji Heteroskedastisitas digunakan untuk mengetahui apakah ada perbedaan antara variance dari observasi yang satu dengan observasi yang lain, jika residual mempunyai varians yang sama disebut homoskedastisitas dan jika varians tidak sama disebut heteroskedastisitas. Persamaan regresi yang baik jika tidak terjadi heteroskedastisitas. Salah satu cara untuk mendektesi ada atau tidaknya heteroskedastisitas adalah dengan menilai grafik scatterplot antara nilai prediksi variabel dependen ZPRED dengan residualnya SRESID.

Analisis Regresi Linier Berganda. Studi mengenai ketergantungan satu variabel terikat dengan satu atau lebih variabel variabel bebas dengan tujuan untuk mengestimasi dan memprediksi rata-rata populasi atau nilai rata-rata variabel terikat berdasarkan nilai variabel bebas yang di ketahui. Pusat perhatian adalah pada upaya menjelaskan dan mengevaluasi hubungan antara suatu variabel dengan satu atau lebih variabel independen. Berupa anggapan $Y=f\left(X_{1}, X_{2},\right)$ Dalam hubungan fungsional di mana $Y$ adalah fungsi liniear, maka model regresi berganda untuk satu variabel di mana variabel terikatnya merupakan fungsi liniear dari dua variabel bebas. Persamaan model penelitian ini adalah sebagai berikut :

$$
\mathrm{ROE}=\beta \mathrm{o}+\mathrm{DOL} \beta \mathrm{\imath}+\mathrm{DFL} \beta 2
$$

Keterangan :

ROE : Return On Equity.

$D O L$ : Degree Of Operation Leverage.

DFL : Degree Of Financial Leverage.

$\beta$ I...ß3: Koefisien variabel bebas.

\section{HASIL DAN PEMBAHASAN}

Tabel 1. Uji Normalitas

\begin{tabular}{|c|c|c|}
\hline \multicolumn{2}{|c|}{ One-Sample Kolomogorov-Smirnov Test } & \multirow{2}{*}{$\frac{\text { Unstandarized Residual }}{30}$} \\
\hline $\mathrm{N}$ & & \\
\hline \multirow[t]{2}{*}{ Normal Parameters ${ }^{a, b}$} & Mean & .0000000 \\
\hline & Std. Deviation & 02763938 \\
\hline \multirow[t]{3}{*}{ Most Extreme Differences } & Absolute &, 155 \\
\hline & Positive & 151 \\
\hline & Negative &,- 155 \\
\hline Test Satistic & & 155 \\
\hline Asymp. Sig. (2Tailed) & &, $064^{c}$ \\
\hline
\end{tabular}

Berdasarkan Tabel 1 yang merupakan hasil uji normalitas dengan menggunakan uji One Sample Kolmogorov Smirnov dapat diketahui dengan jumlah N 30 bahwa nilai Asymp. Sig lebih besar dari 0,05 yaitu sebesar $0,064(0,064>0,05)$ sehingga dapat disimpulkan bahwa nilai residual berdistribusi normal. 
Tabel 2. Uji Autokorelasi

\begin{tabular}{cc}
\hline Model & Durbin-Watson \\
\hline 1 & 1,769 \\
& Predictor: DOL \& DFL \\
& Dependent: ROE \\
\hline
\end{tabular}

Tabel 2 menunjukan bahwa nilai $D-W$ pada model regresi sebesar 1,769 . Nilai ini dibandingkan dengan nilai tabel menggunakan nilai signifikan 5 persen, jumlah sampel 30 (N) dan jumlah variabel independen $3(\mathrm{~K}=3)$, maka di tabel Durbin Watson akan didapatkan nilai secara matematis dapat diperoleh nilai $\mathrm{dl}=1,2138$ dan nilai $\mathrm{du}=1,6498$ maka dapat disimpulkan 1,2138<1,769<3-1,6498 maka dapat disimpulkan tidak terjadi autokorelasi.

Tabel 3. Uji Multikolinearitas

\begin{tabular}{lcc}
\multicolumn{1}{c}{ Model } & \multicolumn{2}{c}{ Colinearity Statistics } \\
& Tolerance & VIF \\
\hline 1 (Constant) & & \\
DOL &, 898 & 1,114 \\
DFL &, 924 & 1,083 \\
Dependent: $R O E$ & & \\
\hline
\end{tabular}

Diketahui nilai VIF masing-masing variabel independen yaitu Degree of Operation Leverage sebesar 1,114 dan Degree of Financial Leverage sebesar 1,083. Berdasarkan Tabel 3 diketahui pula nilai tolerance masing-masing variabel independen yaitu Degree of Operation Leverage sebesar 0,898 dan Degree of Financial Leverage sebesar 0,924. Kedua variabel bebas tersebut memiliki nilai VIF di bawah 10 dan nilai Tolerance di atas 0,1 maka dapat disimpulkan bahwa tidak terjadi multikolinieritas antar variabel independen.

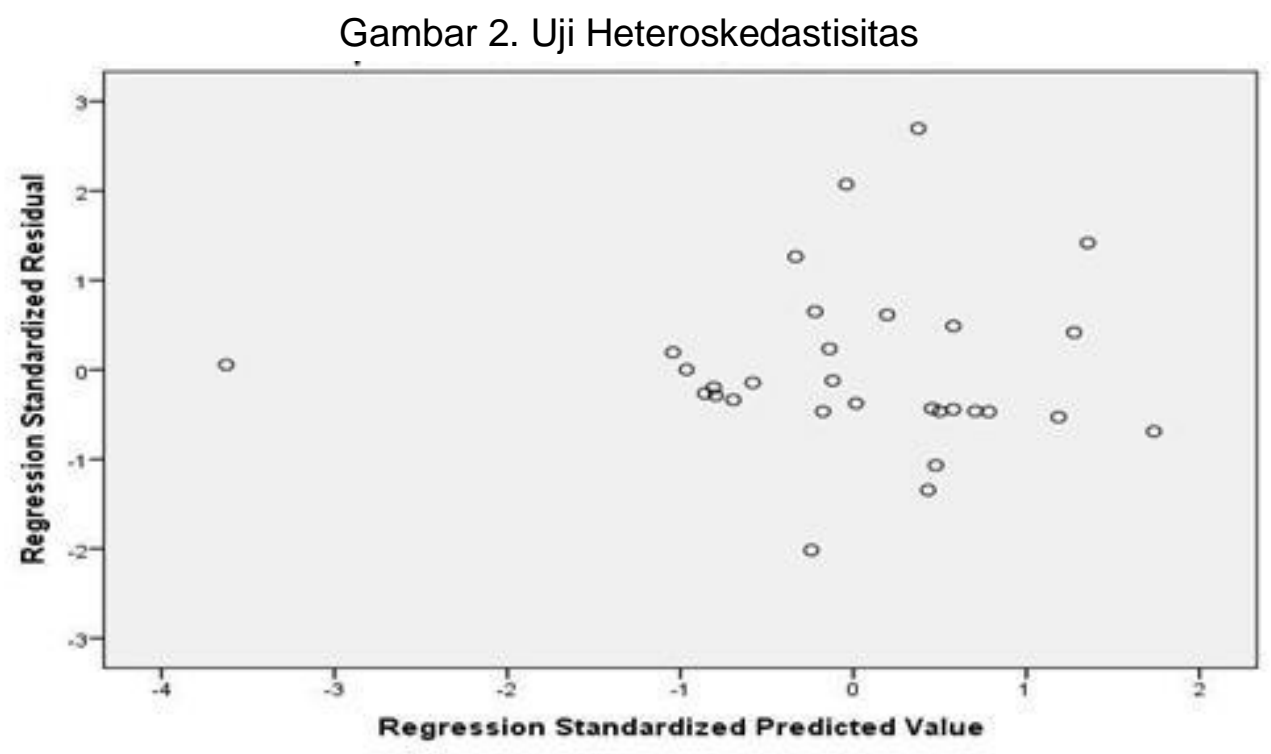

Uji heteroskedastisitas yang dihasilkan dalam Gambar 2 menunjukkan tidak ada pola yang jelas serta titik-titik menyebar diatas dan di bawah angka 0 pada sumbu $Y$ maka dapat disimpukan bahwa tidak terjadi heteroskedastisitas. 
Tabel 4. Uji F

\begin{tabular}{ccc}
\hline Model & F & Sig. \\
\hline 1 Regression & 3,138 &, $936^{\mathrm{b}}$ \\
Residual & & \\
Total Predictor : DOL \& DFL & & \\
Dependent : $R O E$ & & \\
\hline
\end{tabular}

Berdasarkan Tabel 4, $F_{\text {hitung }}$ sebesar 0,138 dengan nilai signifikasi 0,936, karena signifikansinya lebih besar dari 0,05 maka dapat disimpulkan bahwa Degree of Operation Laverage dan Degree of Financial Laverage secara simultan tidak berpengaruh signifikan terhadap ROE.

Tabel 5. Koefisien Determinasi

\begin{tabular}{cc}
\hline Model & $\mathbf{R}^{2}$ \\
\hline 1 & 0,16 \\
DOL & 0,07 \\
DFL & 0,09 \\
\hline
\end{tabular}

Berdasarkan Tabel 5, menunjukan bahwa variabel Degree of Operation Laverage dan Degree of Financial Laverage menentukan variasi variabel Return on Equity sebesar 16 persen sedangkan sisanya sebesar 84 persen ditentukan oleh variabel-variabel lain yang lain yang tidak dianalisis dalam penelitian.

Tabel 6. Regresi Linier Berganda

\begin{tabular}{lrrrr}
\hline \multicolumn{1}{c}{ Model } & \multicolumn{2}{c}{ Unstandardized Coeficients } & \multicolumn{1}{c}{$\boldsymbol{t}$} & \multicolumn{1}{c}{ Sig. } \\
\hline 1(Constant) & $\boldsymbol{B}$ & \multicolumn{1}{c}{ Std. Error } & &, 192 \\
DOL &, 016 &, 012 & 1,341 &, 787 \\
DFL &,- 1.17114 &, 000 & $-2,272$ &, 712 \\
Dependent: $R O E$ &, 055 &, 147 &,- 373 & \\
\hline
\end{tabular}

Hasil analisis regresi linear berganda dalam Tabel 6 diperoleh koefisien variabel Degree of Operation Leverage sebesar -1,17114 dan koefisien variable Degree of Financial Leverage sebesar 0,055 dengan konstanta 0,016.

Analisis regresi linier berganda menunjukan bahwa nilai signifikansi variabel Degree of Operation Leverage 0,787. Nilai signifikansi tersebut lebih besar dari 0,05 maka dapat disimpulkan bahwa variabel Degree of Operation Leverage secara parsial tidak berpengaruh signifikan terhadap Return on Equity. Hasil penelitian ini mendukung hasil penelitian Ayu (2011), Yahya (2011), dan Hadipranoto (2005) bahwa Degree of Operating Leverage berpengaruh negatif terhadap ROE. Apabila Degree of Operating Leverage turun dan menimbulkan beban operasi yang rendah maka, akan meningkatkan laba perusahaan. Sebaliknya apabila Degree of Operating Leverage perusahaan naik maka, akan menyebabkan penurunan profitabilitas perusahaan. Hal ini terjadi karena semakin besar biaya produksi yang bersifat tetap maka, semakin besar pula pengaruh leverage sehingga kondisi ini cenderung menekan laba perusahaan. 
Adapun nilai signifikansi variabel Degree of Financial Leverage 0,712. Nilai signifikansi tersebut lebih besar dari 0,05 maka dapat disimpulkan variabel Degree of Financial Leverage secara parsial tidak berpengaruh signifikan terhadap Return on Equity. Hasil penelitian ini mendukung hasil penelitian Ayu (2007) dan Hadipranoto (2005) bahwa Degree of Financial Leverage berpengaruh negatif terhadap ROE, jadi semakin tinggi Degree of Financial Leverage maka semakin besar risiko keuangannya. Peningkatan risiko yang dimaksud adalah kemungkinan terjadinya gagal bayar (default) karena perusahaan terlalu banyak melakukan pendanaan aktiva dari hutang. Dengan adanya risiko gagal bayar, maka biaya yang harus dikeluarkan oleh perusahaan untuk mengatasi masalah ini semakin besar. Semakin rendah Degree of Financial Leverage, maka akan semakin tinggi kemampuan perusahaan untuk membayar seluruh kewajibannya yang berarti bahwa hanya sebagian kecil aktiva perusahaan dibiayai oleh hutang. Degree of Financial Leverage yang menurun disebabkan peningkatan total aktiva yang lebih besar dibandingkan peningkatan hutang sehingga dapat menurunkan beban hutang yang mengakibatkan Return of Equity yang dihasilkan meningkat. Hasil penelitian ini sesuai dengan teori Pecking Order yang menyatakan bahwa perusahaan lebih menyukai pendanaan yang berasal dari dana internal yaitu laba ditahan daripada pendanaan yang berasal dari dana ekternal yaitu hutang.

Adanya pengaruh yang tidak signifikan dapat diartikan bahwa ada perusahaan sub sektor makanan dan minuman yang memiliki hutang tinggi dan laba tinggi, tetapi ada juga perusahaan yang memiliki hutang tinggi namun laba rendah. Oleh karena itu tinggi rendahnya Degree of Financial Leverage pada perusahaan tidak akan berpengaruh pada profitabilitas perusahaan tersebut. Di sisi lain tingginya rasio Degree of Financial Leverage Ratio mengindikasikan adanya dana besar dari sumber hutang yang dapat dimanfaatkan dalam operasional perusahaan dalam meningkatkan profitabilitas. Dengan demikian Degree of Financial Leverage yang sangat tinggi akan menurunkan profitabilitas perusahaan karena meningkatnya biaya bunga dan resiko gagal bayar, namun apabila Degree of Financial Leverage meningkat dengan wajar akan membantu kemampuan pendanaan operasional perusahaan tersebut dalam rangka meningkatkan profitabilitas.

\section{KESIMPULAN}

Berdasarkan analisis hasil penelitian yang dilaksanakan pada perusahaan manufaktur subsektor makanan dan minuman yang terdaftar di Bursa Efek Indonesia periode 2011 - 2016 maka dapat disimpulkan baik Degree of Operational Leverage maupun Degree of Financial Leverage tidak berpengaruh signifikan terhadap Return on Equity. Pengaruh yang tidak signifikan menunjukkan bahwa ada perusahaan yang memiliki hutang tinggi dan laba tinggi, tetapi ada juga perusahaan yang memiliki hutang tinggi namun laba rendah. Oleh karena itu tinggi rendahnya Degree of Operational Leverage dan Degree of Financial Leverage pada perusahaan tidak akan berpengaruh pada Return on Equity perusahaan tersebut.

Perlu adanya tindakan kehati-hatian investor dalam berinvestasi pada perusahaan dengan struktur hutang yang tinggi karena memiliki risiko kebangkrutan yang tinggi. Investor disarankan untuk memilih berinvestasi pada perusahaan besar yang lebih mapan dari sisi total asset dan perusahaan yang memiliki tingkat profitabilitas yang baik. 


\section{DAFTAR PUSTAKA}

Ayu, Luh Putu. 2007. Analisis Pengaruh Cyclicality, Operating Leverage, Firm Size dan Financial Leverage Terhadap Business Risk Pada Industri Makanan (Minuman) Dan Property (Real Estate) Yang Terdaftar Di Bursa Efek Jakarta. Jurnal Manajemen. Volume 3, No. 2.

Ayu, K. 2011. Analisis Pengaruh Financial Leverage Terhadap Earning Per Share Pada Perusahaan Makanan Dan Minuman Di Bursa Efek Indonesia. Jurnal Ekonomi Manajemen. Volume 15, No. 1.

Ghozali, Imam. 2006. Aplikasi, Multivariat dengan Program SPSS. Semarang : Badan Penerbit Universitas Diponegoro.

Hanafi, M. Mamduh. 2010. Manajemen Keuangan. Yogyakarta : BPFE.

Husnan, Suad. 2006. Dasar-dasar Manajemen Keuangan. Yogyakarta : UPP STIM YKPM.

Kasmir. 2008. Analisis Laporan Keuangan. Jakarta : Rajawali Pers.

Mustika Hadipranoto. 2005. Pengaruh Financial Leverage terhadap Profitabilitas Perusahaan Manufaktur yang Go-public di Indonesia. Tesis. Fakultas Ekonomi Universitas Katolik Soegijapranata.

Sugiyono. 2008. Metode Penelitian Kuantitatif, Kualitatif dan $R \& D$. Bandung : Alfabeta

Tandelilin, Eduardus. 2011. Analisis Investasi dan Manajemen Portofolio. Yogyakarta: BPFE.

Tania, Lisa. 2013. Analisis Pengaruh Cash Position, Debt to Equity Ratio (DER), Return on Asset (ROA), Cash Ratio, Asset Growth, dan Firm Size terhadap Dividend Payout Ratio. Jurnal Ekonomi. Volume 8, No. 2.

Warsono. 2003. Manajemen Keuangan Perusahaan. Jilid I. Malang: Bayumedia Publishing.

Yahya, Syarief Dienan. 2011. Analisis Pengaruh Leverage Keuangan Terhadap Profitabilitas Pada Perusahaan Telekomunikasi Yang Terdaftar Di BEl. Skripsi, Fakultas Ekonomi Universitas Hasanuddin. 